\title{
THE INNOVATIVE ACTIVITY OF ENTERPRISES AS A PREREQUISITE FOR SUSTAINABLE ECONOMIC DEVELOPMENT
}

\author{
Olena Arefieva', Samira Piletska² \\ National Aviation University, Ukraine \\ Serchii Arefiev ${ }^{3}$ \\ Kyiv National University of Technology and Design, Ukraine
}

\begin{abstract}
In terms of exacerbation of crisis processes in the economy, hindering trends in upgrading technologies are observed, which leads to a certain lag from modern needs for the reproduction of productive forces. In order to solve this problem, it is necessary to consider the innovative activity as a factor and a consequence of hierarchical changes in related levels and fields that allows a researcher to deepen into the selected area and develop it in more detail from the chosen position. The presence of innovative activity leads to technological shifts that are carried out by using technologies of another technological mode. In such conditions, the innovative activity of enterprises, which serves a basis for sustainable development of the economy, is an important component and prerequisite for sustainable economic development. The purpose of the article is to analyse the nature of the innovative activity of enterprises, study issues of providing sustainable economic development by developing a mechanism of innovative activity of an enterprise, taking into account its innovative space. To achieve this purpose, there are the following tasks: to analyse trends in innovative processes and innovative activity of enterprises by corresponding directions; substantiate factors of innovative activity by levels of the economy and determine their effect by components; propose a mechanism of innovative activity by levels of the economy in order to stimulate enterprises to introduce innovations for ensuring increased capacity of activities. Methodology. The methodological basis of the article is methods of scientific cognition, which allow revealing the nature of the innovative activity of enterprises, the main laws of innovative development of the economy, priority ways to ensure their financial firmness. In particular, the following methods are used: analysis and synthesis - when studying the innovative activity of enterprises in 2001-2016; systematization - for revealing factors hindering the innovative activity of enterprises; scientific abstraction - in order to form a theoretical generalization and conclusions. Results. There are substantiated factors of influence on the innovative activity of all economic levels per unit of influence that is proposed to be considered a business process, which stipulate for the operation of the effective mechanism of business process management that contributes to the intensification of the enterprises'innovative activity. The proposed mechanism of innovative activity by levels of the economy allows forming it aimed at creating an active innovation space, which establishes feedback with the innovative climate, which creates information capabilities for its adaptation to changing conditions of the environment in the aspect of development and introduction of modern innovative equipment. Further research directions are aimed at deepening the interconnection of innovative climate in Ukraine and innovative space and its characteristics, which is an integral component of intensification of innovative activity. Practical implications. Practical implications are related to the possibility of using the proposed mechanism of the increase in innovative activity of enterprises, providing the efficiency of managerial influences when introducing modern technology, and improving the production quality. Value/ originality. Originality lies in the substantiation of relevant factors that influence and determine directions of innovative activity of enterprises, which allow combining the study of active business processes and financial planning and creating information support for compliance.
\end{abstract}

Key words: sustainable development, mechanism, innovative activity, factors, compliance, levels of economy, business process.

\section{JEL Classification: $\mathrm{O} 31, \mathrm{~F} 63$}

\footnotetext{
Corresponding author:

${ }^{1}$ Department of Air Transport Economics, National Aviation University.

E-mail: Lena-2009-19@ukr.net

${ }^{2}$ Department of Finance, Accounting and Auditing, National Aviation University.

E-mail:0508486185@ukr.net

${ }^{3}$ Department of Entrepreneurship and Business, Kyiv National University of Technology and Design.

E-mail: arefievso@ukr.net
} 


\section{Introduction}

In terms of exacerbation of crisis processes in the economy, hindering trends in upgrading technologies are observed, which leads to a certain lag from modern needs for the reproduction of productive forces. There is the development of innovative processes aimed at activisation of knowledge use for the increase in social production based on innovative potential and the maximum satisfaction of consumer needs in innovative products. In order to solve this problem, it is necessary to consider innovative activity as a factor and a consequence of hierarchical changes in related levels (mega-, macro-, mesa-, and micro-levels) and fields (as a source of orders for qualitatively new raw and other materials, semi-finished products, services) that allows a researcher to deepen into the selected area and develop it in more detail from the chosen position. The presence of innovative activity leads to technological shifts that are carried out by using technologies of another technological mode. In such conditions, the innovative activity of enterprises, which serves a basic prerequisite for the formation and a basis for sustainable development of the economy, is an important component of sustainable economic development.

\section{Literature review}

Modern fundamentals of innovative development were studied in works of such domestic scholars as: Bielikova (2014), Vakhovych (2012), Melnyk \& Shkarupa (2011), Yurkevych (2010) and others.

Growing interest of scholars to the issue of management of innovative processes at enterprises is determined by the improving role of innovations in their activities, namely, in scientific works of the following authors: Boichuk, (2016); Varfolomiieva, (2009); Voloshchuk, (2015); Demydenko, (2015); Doroshuk, (2010); Illiashenko, (2008); Shypulina, Illiashenko, Pererva \& Kosenko (2012); Polinkevych, (2011); Sotnyk, \& Shevtsov, (2013); Uvarova, Hnylobokov \& Boiakova, (2010); Yurkevych, (2010); Yastremska \& Dourtmes, (2016).

Along with that, a large number of works in the field of innovative activity of enterprises require its further disclosing as a prerequisite for sustainable development of the economy and remain unsolved from the viewpoint of system multilevel approach and based on the engagement of knowledge economy. This is what will contribute to the formation of changes in the functional imperative of management at all levels during the transition to innovative development model.

\section{Goals and tasks of the article}

The purpose of the article is to analyse the nature of the innovative activity of enterprises, study issues of providing sustainable development of the economy by developing a mechanism of innovative activity of an enterprise, taking into account its innovative space.

To achieve this purpose, there are the following tasks: to analyse trends in innovative processes and innovative activity of enterprises by corresponding directions; substantiate factors of innovative activity by levels of the economy and determine their effect by components; propose a mechanism of innovative activity by levels of the economy in order to stimulate enterprises to introduce innovations for ensuring increased capacity of activities.

\section{The main material of the research}

In the era of knowledge economy, innovations become a driving force of development; they, on the one hand, are a result of innovative activity and, on the other hand, are a component of formation of the enterprise's strategy, changing market condition and a basic component of development, which is evidenced by characteristics of corresponding technological modes. By using a process approach as an essential characteristic and technology for conducting the innovative activity, enterprises will be able to achieve the necessary innovative activity. It is innovatively active economic entities that should be the basis for qualitative changes in industries that are able to introduce innovative technology and products for the productive and personal consumption and to develop innovative potential.

It should be noted that innovative activity is not widespread yet in Ukraine as the share of enterprises engaged in innovations in 2016 was $18.9 \%$, i.e. almost 2-2.5 times less compared to developed countries. However, total research-and-development spending and costs of modern equipment purchasing more precisely characteriseinnovative processes in the national economy; so, in 2014 , this sum amounted to 7695.9 million hryvnias (at dollar's market value of 12-13 hryvnias), and in 2016 23229.5 million hryvnias (at dollar's market value of 26-27 hryvnias) (Table 1), which testifies about negative tendencies in the innovation sphere and hindering development on qualitatively new basis of technical and technological support.

The innovative activity of an enterprise (economic entity) requires additional consideration and interpretation from the position of system multilevel approach, which will allow intellectualizing its potential in whole, and competencies, in particular, since it is based on knowledge and awareness of this activity's participant. As a result, an innovative capacity of the enterprise is created, which ensures implementation of changes in production technologies and labour organization, managerial innovations that make an influence on the selection of organizational structure model and its adaptation, its functionality and corporate culture, capacity of workers to think outside of the box and produce ideas. 
Table 1

Innovative activity, million UAH

\begin{tabular}{|c|c|c|c|c|c|c|c|c|c|}
\hline \multirow[b]{3}{*}{ Year } & \multirow{3}{*}{$\begin{array}{c}\text { Share of } \\
\text { enterprises } \\
\text { engaged in } \\
\text { innovations, } \\
\%\end{array}$} & \multirow[b]{3}{*}{ Total costs } & \multicolumn{7}{|c|}{ Including by directions } \\
\hline & & & \multirow[b]{2}{*}{$\begin{array}{l}\text { research and } \\
\text { development }^{1}\end{array}$} & \multicolumn{2}{|c|}{ including } & \multirow{2}{*}{$\begin{array}{c}\text { acquisition } \\
\text { of other } \\
\text { external } \\
\text { knowledge }^{2}\end{array}$} & \multirow{2}{*}{$\begin{array}{l}\text { preparation of } \\
\text { production for } \\
\text { introducing } \\
\text { innovations }{ }^{3}\end{array}$} & \multirow{2}{*}{$\begin{array}{c}\text { acquisition } \\
\text { of machinery, } \\
\text { equipment, } \\
\text { and software }\end{array}$} & \multirow[b]{2}{*}{ other costs } \\
\hline & & & & $\begin{array}{c}\text { internal } \\
\text { R\&D }\end{array}$ & $\begin{array}{l}\text { external } \\
\text { R\&D }\end{array}$ & & & & \\
\hline 2001 & 16,5 & 1979,4 & 171,4 & $\mathrm{X}$ & $\mathrm{X}$ & 125,0 & 183,8 & 1249,4 & 249,8 \\
\hline 2002 & 18,0 & 3018,3 & 270,1 & $\mathrm{X}$ & $\mathrm{X}$ & 149,7 & 325,2 & 1865,6 & 407,7 \\
\hline 2003 & 15,1 & 3059,8 & 312,9 & $\mathrm{X}$ & $\mathrm{X}$ & 95,9 & 527,3 & 1873,7 & 250,0 \\
\hline 2004 & 13,7 & 4534,6 & 445,3 & $\mathrm{X}$ & $\mathrm{X}$ & 143,5 & 808,5 & 2717,5 & 419,8 \\
\hline 2005 & 11,9 & 5751,6 & 612,3 & $\mathrm{X}$ & $\mathrm{X}$ & 243,4 & 991,7 & 3149,6 & 754,6 \\
\hline 2006 & 11,2 & 6160,0 & 992,9 & $\mathrm{X}$ & $\mathrm{X}$ & 159,5 & 954,7 & 3489,2 & 563,7 \\
\hline 2007 & 14,2 & 10821,0 & 986,4 & 793,5 & 192,9 & 328,4 & $\mathrm{X}$ & 7441,3 & 2064,9 \\
\hline 2008 & 13,0 & 11994,2 & 1243,6 & 958,8 & 284,8 & 421,8 & $\mathrm{X}$ & 7664,8 & 2664,0 \\
\hline 2009 & 12,8 & 7949,9 & 846,7 & 633,3 & 213,4 & 115,9 & $\mathrm{X}$ & 4974,7 & 2012,6 \\
\hline 2010 & 13,8 & 8045,5 & 996,4 & 818,5 & 177,9 & 141,6 & $\mathrm{X}$ & 5051,7 & 1855,8 \\
\hline 2011 & 16,2 & 14333,9 & 1079,9 & 833,3 & 246,6 & 324,7 & $\mathrm{X}$ & 10489,1 & 2440,2 \\
\hline 2012 & 17,4 & 11480,6 & 1196,3 & 965,2 & 231,1 & 47,0 & $\mathrm{X}$ & 8051,8 & 2185,5 \\
\hline 2013 & 16,8 & 9562,6 & 1638,5 & 1312,1 & 326,4 & 87,0 & $\mathrm{X}$ & 5546,3 & 2290,9 \\
\hline $2014^{5}$ & 16,1 & 7695,9 & 1754,6 & 1221,5 & 533,1 & 47,2 & $\mathrm{X}$ & 5115,3 & 778,8 \\
\hline $2015^{5}$ & $17,3^{6}$ & 13813,7 & 2039,5 & 1834,1 & 205,4 & 84,9 & $\mathrm{X}$ & 11141,3 & 548,0 \\
\hline $2016^{5,7}$ & 18,9 & 23229,5 & 2457,8 & 2063,8 & 394,0 & 64,2 & $\mathrm{X}$ & 19829,0 & 878,4 \\
\hline
\end{tabular}

${ }^{1}$ sum of internal and external R\&D since $2007 ;{ }^{2}$ acquisition of new technology until $2007 ;{ }^{3}$ since 2007 the indicator is included with other costs; ${ }^{4}$ till 2007 acquisition of machinery and equipment, related to the introduction of innovations; ${ }^{5}$ data is provided without including temporarily occupied territory of the Autonomous Republic of Crimea, Sevastopol, and a part of Anti-Terrorist Operation Zone; ${ }^{6}$ in relation to changes in organization and conduct of state statistical survey on innovative activity of an industrial enterprise, a direct comparison of data for 2015 with analogous data of previous years is incorrect; ${ }^{7}$ data is provided according to results of the state statistical survey on form № IHH "Investigation of Innovative Activity of Enterprises for 2014-2016" (by international methodology).

Source: (Official site of the State Statistics Service of Ukraine)

So far as an innovative activity not only changes qualitative characteristics of the economy, industry, enterprise but also creates new qualities of consumption that are based on needs of the people who conduct this activity. This is what enables creating a multiplicative effect both in production and non-production sphere by requiring using the latest technology, creating preconditions for the innovativeness of management at all levels, and basing on the prediction of transformation changes.

The increase of disproportions in the economy is explained, first of all, by different vector directions of regulatory influences on the innovative activity of enterprises, which is a prerequisite for sustainable economic development (Fig. 1). This is especially reflected in the system-forming industries, which are construction, engineering, transport, agro-industrial complex, and some others.

Therefore, it should be noted that the blocking of any element (at levels) of the economy as a socio-economic system leads to the destruction of links between the elements over the discrepancy of the pace of innovation and investment activity of more than $30 \%$, violates the adaptability of resources use and the organization of functional systems. Moreover, a set of factors that hinder the innovative activity of enterprises can be distinguished:
- the high cost of research and development work, as well as their duration, limit the number of business entities capable of carrying them out and releasing for this purpose funds from circulation sufficient to ensure the continuity of such works and minimizing financial threats to business;

- limited state support and budget funding for the development and implementation of innovative products. Thus, on average for 2005-2013, the share of budget financing of innovations in total expenditures in Ukraine was within the range of 1.0-1.6\% (IlnytskaHykavchuk, 2015), and in $2016-0.8 \%$;

- the imperfection of the implementation of the stimulating function of taxation of innovative products over the lack of appropriate privileges and underdevelopment of mechanisms for accelerated depreciation when updating fixed assets for this;

- the lack of diversification of banking lending because of high-interest rates of venture projects, due to their duration and high risks of non-repayment of funds due to non-predictability of results;

- high depreciation of the active part of the capital of enterprises, which does not allow to find the technical and technological basis for their testing and introduction into the production process on qualitatively new grounds, as well as the need to train the personnel of 
the appropriate qualification and capable of perceiving innovations;

- impossibility to reliably determine the demand for innovative products, which is characterized by flexibility, high costs of researching the market, informing and stimulating demand, taking into account psychological peculiarities, based on changing consumer requirements.

The pace of innovation is slowed down by the lack of experience in managing innovation at all levels, based on internal motivation for action through entrepreneurial activity, which is based on a creative initiative. Therefore, in order to stimulate innovation activity of an enterprise, it is necessary to select the unit of influence, which should be considered business process and structured. So, N.Ya. Boichuk believes that the main stage in the enterprise organization is the classification of business processes. They are divided into four categories. The first category is the main business processes, which are focused on production. They provide acquisition of income. The second category is providing business processes. They provide all processes that take place in the enterprise with resources and services. The third category is managerial business processes. They cover business management functions. The fourth category is business development processes. They are business processes of innovation (Boichuk, 2016). Such an approach to the division of business processes in the enterprise activity is based on the principles of functional and cost analysis as a way to save costs in production and consumption of the product, within which the gradation of the processes itself as a function is made, and the cost of its implementation is determined, which may become the basis to form a mechanism for managing business processes for the development of innovation activity, which meets the requirements of the current stage of development of the economy as a whole, and industry, in particular.

It should be noted that (Chekulyna, 2011) proposed the following main stages of the business process management mechanism:

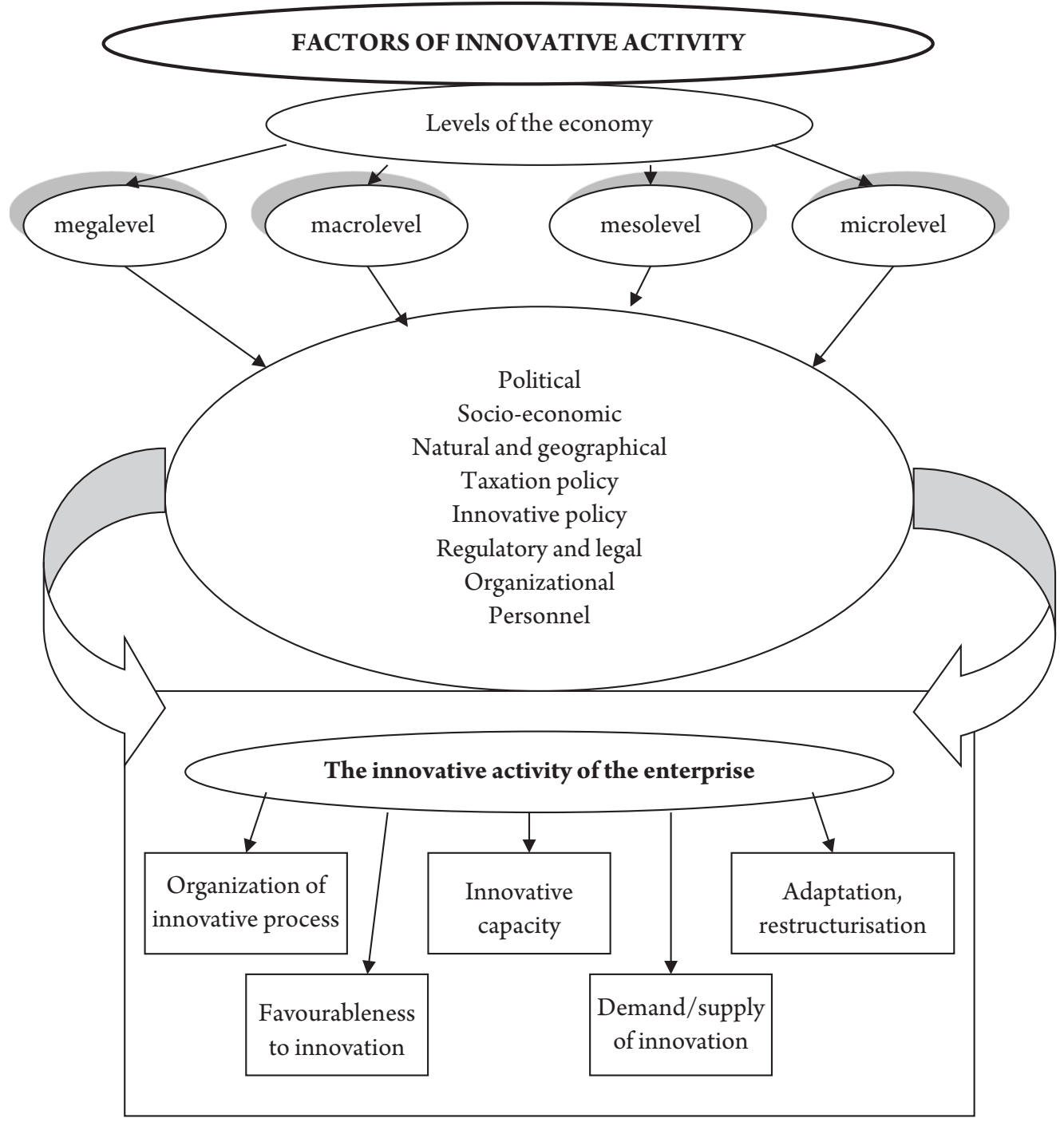

Fig. 1. Factors of innovative activity by levels of the economy (own development) 
- determining the significance of the influence of management levers on business processes;

- identification of priority indicators for improving the effectiveness of the business process;

- definition of measures to improve business processes at the enterprise by the chosen indicator;

- analysis of the influence of innovation activity on the general activity of the enterprise;

- assessment of the efficiency of the operation of the enterprise management mechanism (Chekulyna, 2011), which should be carried out in accordance with its potential regarding the improvement of methods and technology, as well as the modern innovation and investment trends of the economy and industry's development;

- development of compliance of the qualitative and quantitative activity of the enterprise from the standpoint of efficient use of resources and reserves; control elements embedded in business processes to maintain their compliance with external and internal standards;

- management of the tax system at certain levels of the economy in order to optimize cash flows, which stimulates innovation activity and optimizes the tax burden of the enterprise and creates preconditions for applying the methods and elements of compliance;

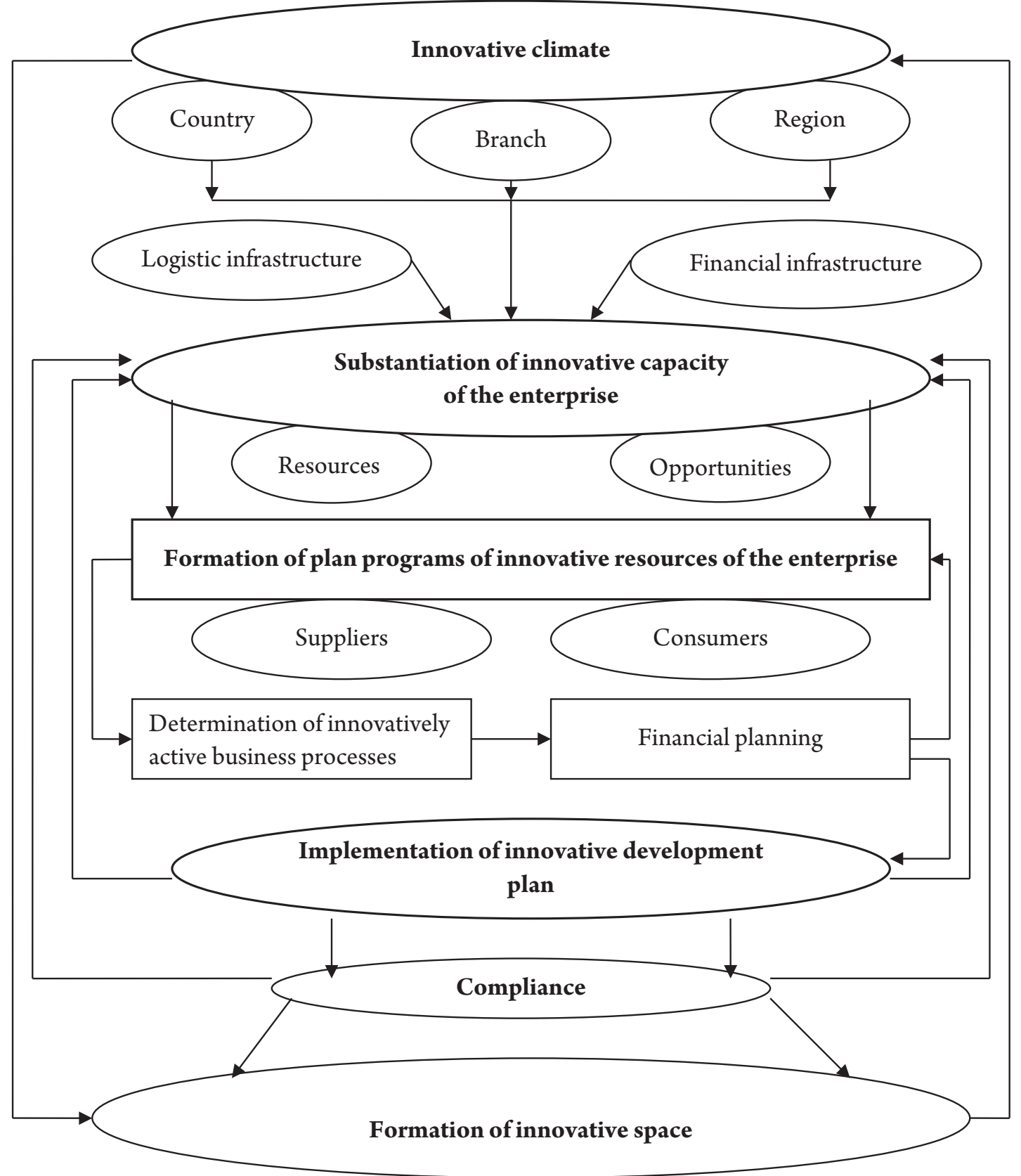

Fig. 2. The mechanism of innovation activity by levels of the economy (own development) 
- formation of stimulating influences of innovative activity of employees, which provides technological development and use of the updated potential of the enterprise due to the formation of innovation space.

It should be noted that the profitability of the enterprise, provided by the continuous implementation of organizational and technological innovations, depends on the synchronization of stages of the lifecycle of various products, when the excess of funds from profitable products or services provides the costs for the development of innovation, the maturity of which compensates for the reduction of profitability of already developed and "worked" products or services. This will smooth out "big waves" of financial results, caused by cyclical fluctuations of cash flows from the sale of a product or service at different stages of its lifecycle (Ilnytska-Hykavchuk, 2015).

Since innovative development should be aimed at ensuring the competitiveness of the enterprise-producer both in the domestic and foreign markets through the creation of greater consumer value for the consumer, which is the main precondition for its competitive advantage. In our opinion, the establishment and strengthening of this cost-and-value production direction form the essence of transformations of innovative enterprises that are capable of creating their higher added value.

To activate and intensify components of the innovation process, an appropriate mechanism (Fig. 2), which is based on a combination of the innovative climate at all levels of the national economy as a prerequisite for the use of logistics and financial infrastructure, is proposed.

A separate stage includes the justification of the innovative potential of the enterprise, which allows forming planned programs of its innovative reserves and is based on the study of the market of consumers, suppliers, and the identification of innovative business processes, which in the vast majority are conditioned by the quality of financial planning.

The distribution of financial costs for the production and sale of product or service innovations should be consistent with the target priorities for the stage of the life cycle of a particular innovation and ensured by the methods of compliance. In relation to this, it can be argued about the alternation not only of the stages of the product lifecycle but also the stages of functioning of the organizational mechanism for the implementation of innovations: strict regulation of activities aimed at compliance with product (service) standards at initial cost stages and encouraging cooperation between management and subordinates to provide internal initiatives to improve production activities at the stages of increasing the profitability of existing services.

\section{Conclusions and recommendations for the further research}

There are substantiated factors of influence on the innovative activity ofalleconomiclevels perunitofinfluence that is proposed to be considered a business process, which stipulate for the operation of the effective mechanism of business process management that contributes to the intensification of the enterprises' innovative activity. The proposed mechanism of innovative activity by levels of the economy allows forming it aimed at creating an active innovation space, which establishes feedback with the innovative climate, which creates information capabilities for its adaptation to changing conditions of the environment in the aspect of development and introduction of modern innovative equipment.

Further research directions are aimed at deepening the interconnection of innovative climate in Ukraine and innovative space and its characteristics, which is an integral component of intensification of innovative activity.

\section{References:}

Bielikova, N.V., Omarov, Sh.A., \& Kriachko, Ie.M. (2014) Analiz pidkhodiv do otsinky staloho rozvytku krain i rehioniv [Analysis of approaches to assessing the sustainable development of countries and regions] Biznes Inform, no. 9, pp. 8-16.

Boichuk, N.Ya. \& Orel, V.V. (2016) Optymizatsiia upravlinnia biznes-protsesamy na pidpryiemstvakh Ukrainy [Optimization of management of business processes at enterprises of Ukraine] Zbirnyk naukovykh prats Natsionalnoho tekhnichnoho universytetu Ukrainy «KPI», no. 17, pp. 173-180.

Varfolomiieva, V. O. (2009) Pidvyshchennia yakosti i optymizatsiia upravlinnia innovatsiinoiu diialnistiu [Improvement of quality and optimization of innovation activity management]. Aktualni problemy ekonomiky, no. 7, pp. 100-106.

Vakhovych I.M., Vakhovych I.M. \& Tabalova O.Ie. (2012) Systema pokaznykiv diahnostyky rehionalnykh asymetrii staloho rozvytku [System of indicators of diagnostics of regional asymmetries of sustainable development] Visnyk Universytetu bankivskoi spravy NBU, no.3 (15), pp. 86-91.

Voloshchuk L. O. \& Nosovets O. I. (2015) Prohnozuvannia innovatsiinoi aktyvnosti promyslovykh pidpryiemstv instrumentamy imitatsiinoho modeliuvannia biznes-protsesiv [Forecasting of innovative activity of industrial enterprises by means of simulation of business processes]. Ekonomika: realii chasu, no. 6 (22), pp. 147-155.

Demydenko, V.V. (2015) Upravlinnia biznes-protsesamy yak skladova protsesnoho pidkhodu do upravlinnia pidpryiemstvom [Business process management as part of a process approach to enterprise management]. Efektyvna ekonomika, no. 11. Retrieved from: http://www.economy.nayka.com.ua/ ?op=1\&z=4517. 
Doroshuk, H. A. (2010) Proektno-oriientovanyi pidkhid v upravlinni orhanizatsiinymy innovatsiiamy [Project-oriented approach in the management of organizational innovation] Odeskyi natsionalnyi politekhnichnyi universytet. - Odessa National Polytechnic University. no. 11(255), pp. 1. Retrieved from: http://www.ena.lp.edu.ua:8080/bitstream/ntb/20300/1/51-254-258.pdf

Illiashenko, S. M. (2008) Sutnist, struktura i metodychni osnovy otsinky intelektualnoho kapitalu pidpryiemstva [Essence, structure and methodical basis of estimation of enterprise intellectual capital]. Ekonomika Ukrainy, no. 11, pp. 16-26.

Ilnytska-Hykavchuk, H.Ia. (2015) Vprovadzhennia innovatsiinykh pidkhodiv do upravlinnia biznes-protsesamy na pidpryiemstvakh [Implementation of innovative approaches to managing business processes at enterprises] Visnyk Natsionalnoho universytetu «Lvivska Politekhnika», no. 815, p. 479.

Innovatsiina Ukraina 2020 : natsionalna dopovid / za zah. red. V.M. Heitsia ta in. ; NAN Ukrainy. Kyiv, 2015. 336 p. [in Ukrainian]

Melnyk, L. H. \& Shkarupa, O. V. (2011) Rol systemnoho upravlinnia innovatsiiamy v klasternykh formuvanniakh na osnovi eko-oriientovanoho pidkhodu [The role of system management of innovation in cluster formations on the basis of an eco-oriented approach] Marketynh i menedzhment innovatsii, no. 3, pp. 187-196.

Melnyk, L.H. (2016) Teoryia razvytyia system : monohrafyia [Theory of system development: monograph] SaarBriuken, Hermanyia : Palmarium Academic Publishing, 528 p. [in Hermanyia].

Mekhanizm upravlinnia potentsialom innovatsiinoho rozvytku promyslovykh pidpryiemstv: monohrafiia / Iu.S.Shypulina,S.M.Illiashenko, P.H. Pererva, O. P. Kosenko [ta in.]; za red. k.e.n., dotsenta Iu. S. Shypulinoi. Sumy: TOV «DD «Papirus $», 2012,458$ p. [in Ukrainian]

Ofitsiinyi sait Derzhavnoi sluzhby statystyky Ukrainy [Official site of the State Statistics Service of Ukraine]. (n.d.) Retrieved from: http://www.ukrstat.gov.ua.

Pererva, P.H., Kotsysky, D. \& Vereshne Shomoshy M. (2012) Transfer tekhnolohii : monohrafiia [Technology Transfer: Monograph]. Kh. : Virovets A.P. «Apostrof», 668 p. [in Ukrainian].

Polinkevych, O.M. (2011) Monitorynh innovatsiinykh protsesiv promyslovykh pidpryiemstv [Monitors of innovation processes in promises of applications]. Ekonomichnyi forum, no. 2, pp. 284-291.

Sotnyk, Y.N. \& Shevtsov, Y.V. (2013) Upravlenye ynnovatsyonnym resursosberezhenyem na mykrourovne v uslovyiakh transformatsyonnykh yzmenenyi ekonomyky [Management of innovative resource-saving at the micro level in conditions of transformational changes in the economy]. Mekhanizm rehuliuvannia ekonomiky, no. 1, pp. 47-53.

Uvarova, Iu.M., Hnylobokov, I.O. \& Boiakova, N.V. (2010) Udoskonalennia upravlinnia innovatsiinym protsesom pidpryiemstva [Improvement of the management of the innovation process of the enterprise]. Ekonomika pidpryiemstva, no. 4, pp. 30-34.

Chekulyna, T.A. (2011) Funktsyonyrovanye mekhanyzma upravlenyia byznes-protsessamy pry razvytyy ynnovatsyonnoi deiatelnosty [Functioning of the business process management mechanism in the development of innovation activities]. Vestnyk OrelHYET, no. 1(15), pp. 132-140.

Yurkevych, O. M. (2010) Innovatsiine spriamuvannia investytsiinoho potentsialu finansovykh instytutiv [Innovative direction of investment potential of financial institutions] Finansy Ukrainy, no. 10, pp. 81-86.

Yastremska, O.M. \& Dourtmes, P.O. (2016) Innovatsiina diialnist promyslovykh pidpryiemstv: rezultaty otsiniuvannia [Innovative activity of industrial enterprises: results of evaluation]. Biznes Inform, no. 4, pp. 161-168. 